\title{
Driving Dixie Down: Removing the Confederate Flag from Southern State Capitols
}

\author{
James Forman, Jr.
}

On April 9, 1865, General Robert E. Lee conceded, "[T] here is nothing left for me to do but go and see General Grant." The Confederate Army surrendered, and Dixie, the Confederate battle flag, ${ }^{2}$ ceased to fly. But only temporarily. In 1956, for the first time in nearly a century, Georgia resurrected the Confederate symbol by changing its state flag $^{3}$ in symbolic opposition to Brown v. Board of Education. ${ }^{4}$ South Carolina followed suit six years later, 5 hoisting the flag above its state capitol. The following year, Alabama revived Dixie, with Governor George Wallace raising the flag as part of his "Segregation Forever" campaign. ${ }^{6}$ Brown is still the law of the land, yet Dixie remains entrenched.

Last year, in NAACP v. Hunt, the Eleventh Circuit rejected the National Association for the Advancement of Colored People's (NAACP) claim that the Constitution of the United States and federal statutes mandate the removal of

1. JAMES M. MCPHERSON, BATtLE CRY OF FREEDOM 848 (1988).

2. After the Battle of Bull Run, General P.G.T. Beauregard decided that the Union and Confederate national flags were too similar to distinguish in battle. In response, a Confederate battle flag was designed. DEVEREAUX D. CANNON, JR., THE FLAGS OF THE CONFEDERACY 51-52 (1988); see also The Stars and Bars Is Not a Racist Symbol, WASH. POST, Feb. 13, 1988, at A17. The Confederacy actually had three national flags in its short history, in addition to the battle flag. David Treadwell, Symbol of Racism?, L.A. TMES, Mar. 9, 1987, at Al.

3. The Georgia state flag is a replica of the Confederate flag, with the state seal imposed upon the leftmost third. Acts and Resolutions of the General Assembly of Georgia, No. 29, 1 General Acts and Resolutions 38 (1956). In introducing the bill to change the Georgia state flag, Representative Denmark Groover indicated that "this will show that we in Georgia intend to uphold what we stood for, will stand for, and will fight for." Jim Auchmutey, Unraveling the Flag: A Guide to Rebel Colors, ATLANTA J.-CONST., Sept. 29, 1991, at M8; see also Marshall Ingwerson, Rebel Flag Won't Come Down Without a Fight, CHRISTIAN SCI. MONTroR, Mar. 9, 1987, at 3. Senator Jefferson Lee Davis was among the drafters of the bill. The Flag Facts Committee, Georgia Flag Facts at 2 (1990) (pamphlet on file with author).

4. 347 U.S. 483 (1954).

5. 4 H.R.J. Cong. Res. 2261, 94th Gen. Assembly, 2d Sess. (1962).

6. Brief for Appellants at 7, NAACP v. Hunt, 391 F.2d 1555 (11th Cir. 1990) (No. 89-7245).

The resurgence of the rebel flag as a symbol for the white South was not limited to state government. For example, students at the University of Mississippi adopted the flag as their symbol during the late 1940's and 1950's, after a group of students attended a convention of the Dixiecrat party, Strom Thurmond's thirdparty dissent from the Democratic Party and its proposed civil rights reforms. Auchmutey, supra note 5, at M8. In 1982, after much controversy, the University announced that the flag was no longer its official symbol; however, the flag continues to be a staple among many white students at Ole' Miss. Id.

505 
the flag from the Alabama state capitol. ${ }^{7}$ Central to the court's conclusion was the notion that the Hunt plaintiffs' problem involved neither the flag nor the law, but their "own emotions." unequal application of the state policy; all citizens are exposed to the flag. Citizens of all races are offended by its position." "In sum, the court told the plaintiffs to turn elsewhere for relief, because "the federal judiciary is not empowered to make decisions based on social sensitivity." 10

This Note takes issue with the Hunt court. It proceeds in two parts. Part I argues that the Alabama government's flying of the rebel flag violates the Equal Protection Clause of the Fourteenth Amendment because the flag was raised with the intent to discriminate against blacks. Part II argues that flying the flag violates the First Amendment because it is a form of racist government speech that chills the speech rights of blacks.

Throughout, the argument will focus on the harms the Confederate flag presents, the appropriate legal remedies, and the Hunt court's misunderstanding of those harms and remedies. The most fundamental errors in Hunt's analysis of the First and Fourteenth Amendment claims stemmed from the court's reliance, however unconscious, on a number of thoroughly repudiated constitutional tenets. Accordingly, this Note will both argue that removing the Confederate flag is constitutionally required and demonstrate that leftover jurisprudential tendencies continue to serve as barriers to a meaningful conception of the First and Fourteenth Amendments.

\section{THE FOURTEENTH AMENDMENT}

\section{A. The Hunter and Arlington Heights Intent Standards}

The Equal Protection Clause of the Fourteenth Amendment provides that no state may "deny to any person within its jurisdiction the equal protection of the laws." 11 In Washington v. Davis ${ }^{12}$ the Supreme Court ruled that establishing an equal protection violation requires a showing of discriminatory intent; evidence of discriminatory impact alone does not suffice. The Court reaffirmed this holding in Hunter $v$. Underwood, ${ }^{13}$ when it stated, quoting its opinion in

7. NAACP v. Hunt, 891 F.2d 1555 (11th Cir. 1990). A number of other parties joined the NAACP in this suit.

8. Id. at 1565.

9. Id. at 1562.

10. Id. at 1565. In addition to ruling against the plaintiffs on the merits, Hum maintained that their claims were barred by res judicata. $I d$, at 1560-61.

11. U.S. CONST. amend. XIV, §I.

12. 426 U.S. 229, 242 (1976). Although Washington v. Davis was a Fifth Amendment case, the analysis is identical for the Equal Protection Clauses under the Fifth and Fourteenth Amendments.

13. 471 U.S. 222 (1985). 
Village of Arlington Heights v. Metropolitan Housing Development Corp. ${ }^{14}$ that " official action will not be held unconstitutional solely because it results in a racially disproportionate impact.... Proof of racially discriminatory intent or purpose is required to show a violation of the Equal Protection Clause." "15 Determining the existence of discriminatory intent is hardly an easy task. The Supreme Court has, however, provided guidelines by which courts can analyze discriminatory intent claims. Were a court to follow these guidelines faithfully, it would not permit Dixie to remain above the Southern States' capitols.

A plaintiff challenging government policy under the Equal Protection Clause bears the burden of demonstrating, by a preponderance of the evidence, that racial discrimination was a substantial or motivating factor in the adoption of the policy. ${ }^{16}$ Since determining the "motivation behind official action is often a problematic undertaking," 17 courts must look to the context in which actions were taken in order to evaluate the discriminatory intent claim. Accordingly, "[d]etermining whether invidious discriminatory purpose was a motivating factor demands a sensitive inquiry into such circumstantial and direct evidence of intent as may be available." ${ }^{18}$ Such an inquiry might include: (1) evidence of disparate impact; (2) "[t]he historical background of the decision ... particularly if it reveals a series of official actions taken for invidious purposes"; 19 (3) "[t]he specific sequence of events leading up to the challenged decision"; ${ }^{20}$ and (4) legislative or administrative history, especially contemporaneous statements of decisionmakers about their reasons. ${ }^{21}$

Under this discriminatory intent standard, there can be little doubt that racial discrimination was a motivating factor in the Southern States' decisions to hoist Confederate flags. Examining the "sequence of events" in Alabama, for example, shows that the Confederate flag was raised as a symbol of white defiance to court-ordered integration. According to Montgomery newsman Robert Ingram, who testified in Hunt:

14. 429 U.S. 252 (1977) (upholding decision of a local planning commission to deny a rezoning request necessary for construction of proposed low and moderate income housing facility).

15. 471 U.S. at 227-2S (quoting Arlington Heights, 429 U.S. at 264-65). In Hunter, two Alabama citizens, one black and one white, were barred from county voting rolls pursuant to the Alabama Constitution, which provided for the disenfranchisement of persons convicted of crimes involving "moral turpitude." Id. at 223. Each of the disenfranchised voters had been convicted of presenting a worthless check. The Supreme Court unanimously held the statute unconstitutional, on the grounds that the law disproportionately hurt blacks and was enacted with discriminatory intent.

16. $l d$. at 228 .

17. 1 d.

18. Arlington Heights, 429 U.S. at 266.

19. Id. at 267.

20. Id.

21. Id. at 268. Hunter is an example of just such a sensitive inquiry into historical context. The Hunter Court faced the task of determining the intent of legislative proceedings from the Alabama State Convention of 1901. The Court approved the district court's use of evidence that went to establishing a racist context. It accepted the testimony of historians that "the Alabama Constitutional Convention of 1901 was part of a movement that swept the post-Reconstruction South to disenfranchise blacks." Hunter, 471 U.S. at 229. (citing testimony of historians C. Vann Woodward and Sheldon Hackney). 
[O]n Thursday, April 25, 1963, Montgomery braced for a meeting between the late Robert F. Kennedy, then U.S. Attorney General, and Alabama's new Governor George C. Wallace[.] [The] Governor had already announced his plan to 'stand in the door' at the University of Alabama to block admission of two Black students and Kennedy came in a futile effort to talk Wallace out of his stand[.] Two acts of defiance unfolded that day: (1) a group of ladies placed a floral wreath over the Jefferson Davis gold star, their way of making certain that the sacred spot was not touched by Kennedy's feet, and (2) shortly after 7:00 a.m. capitol guards hoisted the Confederate Battle flag. ${ }^{22}$

The flag, Ingram concluded, "has flown ever since."23

An examination of "historical background" in Alabama produces further evidence of an intent to discriminate. George Wallace, the person ultimately responsible for raising the flag in 1963, was engaged in a coordinated campaign to fight integration and black equality. His inaugural speech as governor was entitled, "Segregation Forever!" 24 In addition to standing in the doorway of the University of Alabama to protest the admission of black students, ${ }^{25}$ Wallace surrounded the Birmingham public schools with National Guardsmen in an effort to resist court-ordered integration. ${ }^{26}$ That same year, he sent the National Guard into battle against Birmingham blacks protesting segregation. ${ }^{27}$ Wallace not only mobilized his state's apparatus to combat civil rights initiatives, he also encouraged private citizens to fight. In 1963, Wallace told a state meeting of the White Citizens Council, a middle class version of the KKK: "You are doing a wonderful job, but you should speak with the united voice of 100,000 persons. Go back home and get more members." ${ }^{28}$ Finally, Wallace was notorious for his efforts to discredit individual civil rights leaders. In 1964, he joined with Mississippi Governor Ross Barnett in charging the Kennedys with assisting Martin Luther King's "Racial Red Plot." The Governors accused King of being a Communist, based on his participation in the 1957 convention of the Highlander Folk School, which they identified as a "Communist training school." Wallace introduced evidence into the U.S. Senate record alleging that King belonged to more Communist organizations than anyone in America. ${ }^{29}$ Examined in this context, Wallace's decision to raise the Confederate flag in preparation for his meeting with Kennedy constituted part of his continuing effort to maintain white supremacy. It was, then, a decision made with discriminatory intent.

22. Brief for Appellants at 7, NAACP v. Hunt, 891 F.2d 1555 (11th Cir. 1990) (No. 89-7245).

23. Id.

24. TAYloR Branch, Parting the Waters: America IN The King Years, 1954-63, at 738 (1988).

25. Id. at 821 .

26. $l d$. at 888 .

27. Id. at 891 .

28. JAMES FORMAN, THE MAKING OF BLACK REvOLUTIONARIES 316 (1972) (quoting White Citizens Council advertisement in Selma Times Journal).

29. BRANCH, supra note 24 , at 853 . 
The next stage of the Fourteenth Amendment inquiry involves asking whether the government had legitimate, nondiscriminatory reasons for its decision. To meet its burden the government must "demonstrate that the law would have been enacted without this [racially discriminatory] factor." 30 If the plaintiff shows that the Confederate flag was raised at a time of racial strife, it may strain a state's creativity to explain what legitimate, nondiscriminatory reason compelled it to raise the flag at that particular historical moment. ${ }^{31}$ Although it may be difficult to imagine what evidence a state might introduce to meet the test, certain sorts of evidence clearly would not suffice. According to Alabama, the positive purposes of flying the Confederate flag include its "tourism and preserved historical value" and its status as "a symbol of accomplishment, development, and progress towards racial equality." 32

Hunter demonstrates the inadequacy of these explanations. The Hunter Court considered a similar argument by the State of Alabama, which asserted that it had an interest in denying franchise to those convicted of crimes involving moral turpitude. The Court stated that it would not consider ex post justifications when judging the validity of a statute under an equal protection challenge. The appropriate question was whether the government acted with an intent to discriminate, not whether it was possible to imagine a situation where the same action might be taken without discriminatory intent. ${ }^{33}$ It is not enough, then, for Alabama and other states to provide rationales explaining the benefits the flag currently provides the state. States flying Confederate flags must show that acceptable explanations, such as increasing tourism or providing reminders of racial progress, actually motivated the original decision. As the Alabama case demonstrates, this is not a burden states are likely to meet.

\section{B. The Legacy of Plessy and Pace}

The compelling factual record and unambiguous legal standards seem to make the conclusion that states violate the Equal Protection Clause when they fly Confederate flags inevitable. Yet the Hunt court ruled otherwise, without

30. Hunter v. Underwood, 471 U.S. 222, 228 (1985).

31. The timing of the flag's raising is particularly important in light of the frequency with which one is told that the Confederate flag is not a statement about race or racism, but is instead a celebration of a commitment to Southern history, culture, and independence. See. e.g., Auchmutey, supra note 3, at M8 (quoting University of Mississippi law student defending Confederate flag because "I never saw this flag as against blacks.... It's tradition-it's just Ole' Miss."). To the ex'ent that pride in Southern distinctiveness was manifested and continues to manifest itself at precisely the moments that black citizens assert their rights most vigorously, the Southern investment in history, culture, and independence seems intricately linked to, and may serve as a subterfuge for, a commitment to black subordination.

32. Brief for Appellees at 5, NAACP v. Hunt, 891 F.2d 1555 (11th Cir. 1990) (No. 89-7245).

33. Hunter, 471 U.S. at 232-33. 
conducting the careful historical examination that Hunter and Arlington Heights mandate. ${ }^{34}$

Central to the Hunt court's rejection of the plaintiffs' claim was its implicit reliance on unwelcome jurisprudential tendencies of a previous era. ${ }^{35}$ The Hunt court held first that "there is no unequal application of the state policy; all citizens are exposed to the flag. Citizens of all races are offended by its position." 36 Moreover, the court ruled that the plaintiffs' true problem was not with the law, but with their "own emotions." 37

Understanding the basis of this reasoning requires a brief look at an era when such analysis was commonplace. In 1883, Tony Pace, a black man, and Mary Cox, a white woman, were each sentenced to two years in the state penitentiary for the crime of "living together in a state of adultery or fornication." 38 Pace challenged the constitutionality of the Alabama statutory scheme on the ground that it violated the Equal Protection Clause by penalizing interracial fornication more severely than intraracial fornication. The Supreme Court was unmoved, however, finding no unequal application of the law because both Pace and Cox were subject to the same punishment. ${ }^{39}$

Thirteen years later, Homer Adolph Plessy challenged a Louisiana statute mandating separate train carriages for black and white passengers. Plessy claimed that the state-imposed separation constituted discrimination per se. The Supreme Court flatly rejected Plessy's assertion:

We consider the underlying fallacy of the plaintiff's argument to consist in the assumption that the enforced separation of the two races stamps the colored race with a badge of inferiority. If this be so, it is not by reason of anything found in the act, but solely because the colored race chooses to put that construction upon it. ${ }^{40}$

Although Plessy and Pace have been repudiated, ${ }^{41}$ Hunt's reasoning suggests that the shadow of nineteenth-century civil rights cases continues to fall

34. The court summarily dismissed the evidence of discriminatory intent, focusing instead on the facts that: (1) whites and blacks alike are offended by the flag, and (2) the NAACP had never "requested that the flag be brought down as part of the equitable relief requested" in any of the discrimination suits it had brought in the state since the flag was raised. Hunt, 891 F.2d at 1562.

35. For another discussion of an otherwise repudiated Supreme Court decision retaining a hidden vitality, see Cass R. Sunstein, Lochner's Legacy, 87 CoLUM. L. REv. 873 (1987).

36. Hunt, $891 \mathrm{~F} .2 \mathrm{~d}$ at 1562 .

37. Id. at 1565. While this explanation was provided in the context of the First Amendment argument, the court's Fourteenth and First Amendment analyses have similar jurisprudential foundations and can be evaluated jointly. See infra Part II.A (discussing First Amendment).

38. Pace v. Alabama, 106 U.S. 583, 584 (1883).

39. Id. at 585.

40. Plessy v. Ferguson, 163 U.S. 537, 551 (1896) (emphasis added).

41. See Brown v. Board of Educ., 347 U.S. 483 (1954); McLaughlin v. Florida, 379 U.S. 184 (1964). In McLaughlin, the Supreme Court considered a Florida statute that prohibited unmarried interracial couples from living together. In upholding the statute, the Florida Supreme Court relied on Pace. On review, the U.S. Supreme Court reversed and overruled Pace, saying "Pace represents a limited view of the Equal Protection Clause which has not withstood analysis in the subsequent decisions of this Court." ld. at 188. 
on race discrimination claims presented by African-American plaintiffs. This is both unfortunate and unwarranted, for one of the most profound legal developments of the past forty years has been the judiciary's willingness to cast aside the blinders of the Plessy/Pace era and to adopt a legal vision that recognizes the complex relationship between law and social reality. This contemporary legal vision refuses to evaluate state action in a vacuum and is sensitive to the context and relationships of power.

The foundation for such a vision is none other than Brown v. Board of Education. ${ }^{42}$ In Brown, the Court rejected state assertions that segregated schools could provide equal educational opportunities for black and white children. Brown's holding ultimately was rooted in the understanding that as long as racial discrimination and inequality were firmly embedded in the foundations of American society, separate schools could never educate equally. A court dedicated to a careful examination of social context was able to see that given the South's commitment to black subordination, separate schools could only be understood as an element of the structure of white supremacy. Accordingly, said the Court, "To separate [black children] from others of similar age and qualifications solely because of their race generates a feeling of inferiority as to their status in the community that may affect their hearts and minds in a way unlikely ever to be undone." ${ }^{23}$ While perhaps America would one day achieve sufficient racial equality to make possible an education that was separate yet equal, that day had yet to dawn. ${ }^{44}$

Brown has had profound implications for the adjudication of race discrimination claims. A careful consideration of social context has consistently compelled different analyses, and different results, than the vision endorsed in Hunt. For example, under the rationale of Plessy, Pace, and Hunt, states could have argued that closing their public schools in response to Brown's desegregation order did not constitute an equal protection violation because both blacks and whites were affected equally. States did, in fact, make this argument, but courts sensitive to social and historical context were able to recognize that discrimina-

42. 347 U.S. 483 (1954). Like this Note, Charles Lawrence also argues that Brown has implications for racist speech. Charles R. Lawrence, III, If He Hollers Let Him Go: Regulating Racist Speech on Campus, 1990 DUKE L.J. 431, 438-44. His point, however, differs from mine. Lawrence believes that Brown was a case about regulating racist speech. Segregation, he argues, was a thought as well as a practice. By outlawing the practice of segregation, Brown also outlawed the philosophy: "Properly understood, Brown and its progeny require that the systematic group defamation of segregation be disestablished." Id. at 441 . (emphasis added).

43. Brown, 347 U.S. at 494.

44. My argument that separate schools were unconstitutional because of the social reality of black subordination is similar to Catharine MacKinnon's suggestion that the denial of abortion rights to women is unconstitutional because of the social reality of gender inequality. MacKinnon argues that "short of achieving sexual and social equality-short of changing the context-abortion has offered the only way out .... Until this context changes, only the pregnant woman can choose life for the unborn." Catharine A. MacKinnon, Reflections on Sex Equality Under the Law, 100 Y ALE L.J. 1281, 1317 (1991). Accordingly, suggests MacKinnon, if sex equality existed, the abortion debate would change fundamentally: "[T]he politics of abortion would be so dramatically reframed, and the numbers so drastically reduced, as to make the problem virtually unrecognizable." Id. at 1327. 
tion can often disguise itself as neutral state action. In Griffin v. County School Board, ${ }^{45}$ the Court held that the closing of public schools in response to a desegregation order violated the Equal Protection Clause. The Court rejected the suggestion that the decision to close the schools affected all Prince Edward County students, white and black, equally. "Closing Prince Edward's schools," the Court retorted, "bears more heavily on Negro children in Prince Edward County since white children there have accredited private schools which they can attend, while colored children until very recently have had no available private schools, and even the school they now attend is a temporary expedient." 46

Similarly, under the logic of Pace and Hunt, states could, and did, argue that laws forbidding interracial marriages were compatible with the Equal Protection Clause. In Loving v. Virginia ${ }^{47}$ the State of Virginia argued that "because its miscegenation statutes punish equally both the white and the Negro participants," the statutes "do not constitute an invidious discrimination based upon race." 48 Declaring that the laws were "measures designed to maintain White Supremacy," 49 the Court rejected this argument as inconsistent with the "central meaning of the Equal Protection Clause." 50

A final example of the Court's emphasis on social context when considering civil rights cases is $N A A C P$ v. Button, ${ }^{51}$ in which the Court held that a Virginia statute restricting a lawyer's ability to solicit clients violated the NAACP's First and Fourteenth Amendment rights. While the Court recognized that Virginia had not prosecuted any NAACP lawyer, it ruled that judicial intervention was nonetheless required in light of the circumstances surrounding the adoption and implementation of the legislation. The Court took notice of the particular provision's adoption in 1956 as part of Virginia's counterattack on the civil rights movement:

We cannot close our eyes to the fact that the militant Negro civil rights movement has engendered the intense resentment and opposition of the politically dominant white community of Virginia; litigation assisted by the NAACP has been bitterly fought. In such circumstances, a statute broadly curtailing group activity leading to litigation may easily

\footnotetext{
45. 377 U.S. 218 (1964).

46. Id. at 230. Similarly, in Hall v. Saint Helena Parish School Bd., 197 F. Supp. 649 (E.D. La. 1961), aff'd, 368 U.S. 515 (1962), a statute that authorized the closing of all public schools and provided tuition grants for all students to attend private schools was held unconstitutional even though it would have applied to both blacks and whites. "To speak of this law as operating equally," the court insisted, "is to equate equal protection with the equality Anatole France spoke of: "The law in its majestic equality, forbids the rich as well as the poor to sleep under bridges, to beg in the streets, and to steal bread.'" Id. at 655 .

47. 388 U.S. 1 (1967).

48. Id. at 8 .

49. Id. at 11 .

50. Id. at 12 .

51. 371 U.S. 415 (1963).
} 
become a weapon of oppression, however evenhanded its terms appear. $^{52}$

Thus, the courts in Griffin, Loving, and Button all rejected the Plessy/Pace analysis principally because they took the intuition of Brown seriously and exhibited sensitivity to the social context in which discriminatory state actions take place. Against the backdrop of slavery, segregation, and historic prohibitions on race mixing, it was simply impossible to view legislation prohibiting interracial marriages, education, or legal advocacy as anything but an element of the structure of white supremacy. Accordingly, courts viewed these laws as discriminatory and unconstitutional.

\section{Beyond Plessy and Pace: Understanding Context}

It should be similarly impossible to view the Confederate flag as a symbol that affects all races equally or as one that creates problems only for those incapable of handling their own emotions. In fact, an analysis of the Confederate flag that is sensitive to social context, an analysis of the type mandated by Brown, provides a very different picture of Dixie than that painted by the Hunt court.

The flag's force as a symbol stems from its history. The flag was initially designed as a rallying symbol for Confederate troops heading into battle. ${ }^{53}$ The rebels were fighting for territory, for economic control, and-it goes without saying-for slavery. ${ }^{54}$ The way of life for which the South fought reduced blacks to chattel and left them with "no rights which the white man was bound to respect." 55 For blacks, this way of life meant being torn from their homes in Africa, transported like animals across the ocean, bought and sold at auctions, forced to work in inhuman conditions, and raped, burned, and beaten by their masters. ${ }^{56}$ The Confederate flag glorifies and memorializes this brutal regime.

But the Confederate flag symbolizes more than the Civil War and the slavery era. It also stands for a history of resistance to change in the twentieth century. The Confederate flag has been used throughout this century as a symbol by the Klan, skinheads, and other white supremacists opposed to black demands for equality and constitutional protection. ${ }^{57}$ Furthermore, the flag has

52. Id. at 435-36 (footnotes omitted).

53. The Stars and Bars Is Not a Racist Symbol, supra note 2, at A17.

54. See, e.g., MCPHERSON, supra note 1, at 283-84.

55. Dred Scott v. Sanford, 60 U.S. (19 How.) 393, 407 (1857).

56. Eugene D. GeNovese, Roll, JORDAN, ROLL: THE WORLD THE SLAVEs Made 63-67, 305, 416, 419, 471 (1976); see also STANLEY M. ELKINS, SLAVERY: A PROBLEM IN AMERICAN INSTITUTIONAL AND INTELLECTUAL LIFE (1959); KENNETH M. STAMPP, THE PECULIAR INSTITUTION (1956).

57. Examples of the Confederate flag as a symbol of white supremacists are legion. Tom Metzger, the former Grand Dragon of the Ku Klux Klan and leader of the White Aryan Resistance, who was recently ordered to pay $\$ 12.5$ million in damages for his role in the killing of a black man in Oregon, flew the flag 
been adopted knowingly and consciously by government officials seeking to assert their commitment to black subordination. ${ }^{58}$

By flying the Confederate flag above the capitol dome, state governments send a message..$^{59}$ In part, that message glorifies and memorializes slavery, Jim Crow, and subsequent resistance to change. The message also excludes. As Akhil Amar notes, "Confederate symbols-flags, monuments, and so on-all too easily exclude large numbers of citizens, most notably blacks. The metaphoric exclusion implicit in these symbols is made concrete in the physical exclusion associated with (almost invariably) all-white affairs such as Confederate balls." ${ }^{\prime \prime 0}$ Such an exclusionary message emanating from government is

above his home. John M. Glionna, Unfavorite Son, L.A. TMES, Oct. 30, 1990, at El. Ku Klux Klan and neo-Nazi protestors demonstrating outside the national headquarters of the NAACP carried a Confederate flag along with signs saying "Nuke the NAACP." Paul W. Valentine, Police Boost Security at NAACP, WASH. POST, Jan. 5, 1990, at C1. Two hundred members of the neo-Nazi, Aryan Nations organization carrying Confederate flags and wearing Klan robes and Nazi uniforms commemorated Confederate war hero Sam Davis' birthday in Pulaski, Tennessee, the birthplace of the Klan. Town Closes Shops to Protest Neo. Nazi March, L.A. TMES, Oct. 8, 1989, at A28. A group of Los Angeles skinheads, wearing Confederate flag tattoos, attacked a Middle Eastern couple and baby in a supermarket parking lot. Ashley Dunn \& Jeffrey Miller, "I Had to Stop it," Says Guard Who Held Off Alleged "Skinheads", L.A. TMES, June 1, 1989, at B1. A group of 50 white racists and skinheads celebrated an "Aryan Woodstock"; many of them wore the Confederate flag, as well as other racist and anti-Semitic symbols. Dan Morain \& Robert Chow, Rain Dampens Event as Foes Outnumber "Skinheads" at Rally, L.A. TMEs, Mar. 5, 1989, at A3. The Imperial Wizard of the Invisible Empire of the Knights of the Ku Klux Klan, J. W. Farrands, sporting a Confederate flag button on his lapel, flew from his home in Connecticut to California to protest Martin Luther King's birthday. Louis Sahagun, Marchers in Fontana Fete King, Draw Klan Taunts, L.A. TMES, Jan. 18, 1988, at A3. Members of the Ku Klux Klan have marched from the Washington Monument to the Capitol carrying a Confederate flag and chanting "We are the KKK." Mary Jordan \& Linda Wheeler, 14 Hurt as Anti-Klan Protestors Clash with Police, WASH. POsT, Oct. 29, 1990, at Al.

58. See supra notes 3-6, 22-28 and accompanying text. As discussed, in Georgia, the state flag was redesigned to look like the Confederate flag after the Supreme Court's ruling in Brown v. Board of Education. See supra note 3. At approximately the same time, South Carolina raised the flag above the state capitol. In Alabama, the Confederate flag was raised in 1963 as part of Governor Wallace's "Segregation Forever" campaign.

59. Cf., County of Allegheny v. ACLU, 492 U.S. 573 (1989). In Allegheny, the Court held that the county's display of a creche violated the Establishment Clause, while the display of a menorah next to a Christmas tree did not. In evaluating whether the government was endorsing the message of the creche, the Court noted that "the creche stands alone" as the "single element of the display on the Grand Staircase," "the 'main' and most "beautiful part' of the building that is the seat of the county government." Id. at 595-99 (citation omitted). The Court concluded that "by permitting the display of the creche in this particular setting. the county sends an unmistakable message that it supports and promotes the Christian praise to God that is the creche's central religious message." Id. at 600 (citations omitted). If a court were to apply this analysis analogously to the Confederate flag case, it would conclude that by flying the Confederate flag above the seat of state government, the state is sending the message that it supports and endorses the meaning of the flag.

60. Akhil R. Amar, Civil Religion and its Discontents, 67 TEX. L. REv. 1153, 1167 n.76 (1989) (books review). Mari Matsuda also recognizes the message of exclusion that accompanies a government's tolerance of racist speech:

When hundreds of police officers are called out to protect racist marchers, when the courts refuse redress for racial insult, and when racist attacks are officially dismissed as pranks, the victim becomes a stateless person. Target-group members can either identify with a community that promotes racist speech, or they can admit that the community does not include them.

Mari J. Matsuda, Public Response to Racist Speech: Considering the Victim's Story, 87 MICH. L. REv. 2320, 2338 (1989) (footnote omitted). The exclusionary message is even stronger in the Confederate flag context, where the government not only tolerates racist speech, but is itself the speaker. 
especially problematic in a nation that professes a commitment to democratic self-governance and popular participation.

The selection of an exclusionary symbol to fly above the state capitol is harmful in part because of the effect it may have on the desire and ability of the excluded to participate in the political and legal processes. Additionally, the government's choice of a discriminatory symbol stigmatizes blacks. The knowledge that one's own government has knowingly and willfully chosen an exclusionary, denigrating symbol has a damaging effect. As Lee Bollinger argues, the injury produced by discriminatory state action is more than the denial of a certain benefit. It is also "the thought and message of inferiority, of hatred and contempt, that is communicated by the discriminatory act and that afflicts the human spirit of the victim."61 Brown's approach to discrimination must not be forgotten; hearts and minds weigh heavily in equal protection analysis.

Finally, in light of the historic message the Confederate flag conveys, its current use as a symbol of white supremacy by racial hate groups, and its elevation above the capitol buildings in opposition to demands for black equality, constitutes government endorsement of discrimination by private parties. The Supreme Court has rejected such government approval of private discrimination. In Reitman v. Mulkey, ${ }^{62}$ the Court held that California could not repeal its prohibition of housing discrimination by enacting a constitutional amendment prohibiting state interference with land transfers between private parties. The United States Supreme Court reasoned that the constitutional amendment would "significantly encourage ... private discrimination" and therefore violated the Equal Protection Clause. ${ }^{63}$ The Southern States' tacit approval of racial discrimination through the flying of the Confederate flag is no more conscionable than California's attempt to license housing discrimination through the repeal of an antidiscrimination mandate.

By flying the Confederate flag, then, the states of Georgia, Alabama, and South Carolina have adopted as one of their official state symbols a flag that was conceived in a war defending slavery and that has been used since as a symbol of opposition to black equality. In the process, these states have excluded and stigmatized their black citizens and have also encouraged private discrimination against those citizens.

The Hunt court held otherwise, noting that blacks and whites alike are offended by the flag. I have suggested that Hunt's reasoning is attributable to

61. Lee Bollinger, The Tolerant Society: A Response to Critics, 90 COLUM L. REV. 979, 980 (1990). 62. 387 U.S. 369 (1967).

63. Id. at 381 . In his concurrence, Justice Douglas noted that California's policy "is a form of sophisticated discrimination whereby the people of California harness the energies of private groups to do indirectly what they cannot under our decisions allow their government to do." Id. at 383 (citations omitted). 
the lingering legacy of Plessy and Pace. ${ }^{64}$ Hunt shows that the silent vitality of Plessy and Pace has devastating consequences for plaintiffs combating racially discriminatory state action, for it undermines the ability of victims to persuade courts to treat seriously their discrimination claims. ${ }^{65}$ Moreover, it provides a subterfuge by which state action conceived in discriminatory intent can escape the mandate of the Equal Protection Clause. It is time to do what the Hunt court was unable to do. It is time to put the logic of Plessy and Pace to rest.

\section{THE FIRST AMENDMENT}

While the Fourteenth Amendment may be the first place to turn in the search for a judicial remedy for discriminatory state action, it need not be the only place. In this part I argue that the Confederate flag violates the First Amendment by chilling the desire and ability of black citizens to exercise fully their First Amendment rights. Central to this argument is the understanding that the racist speech at issue here takes a particularly objectionable form: it is racist government speech. That the government is the speaker both increases the extent of the harm the speech produces and allows for a remedy plainly consistent with the First Amendment.

The First Amendment may seem an unlikely source for a solution to the problem presented by the Confederate flag, particularly in light of Charles Lawrence's astute observation that "[m]ost blacks-unlike many white civil libertarians-do not have faith in free speech as the most important vehicle for liberation. The first amendment coexisted with slavery, and we still are not sure it will protect us to the same extent that it protects whites." 66 The fight against state-sponsored racism, however, does not permit the luxury of rejecting constitutional principles because they have not always served as liberating

64. This is not to deny that the Confederate flag might offend the sensibilities of some of Alabama's white citizens, including perhaps Judge Johnson, the author of the opinion. But the flag does much more than irritate blacks. Flying the flag perpetuates a historical process of racial subordination, from which Alabama's whites, no matter how sympathetic they might be, have benefitted. Charles Lawrence has a similar response to those who, like Judge Johnson, see racist speech as a question of "offensiveness:"

The word offensive is used as if we were speaking of a difference in taste, as if I should learn to be less sensitive to words that "offend" me .... There is a great difference between the offensiveness of words that you would rather not hear-because they are labeled dirty, impolite, or personally demeaning - and the injury inflicted by words that remind the world that you are fair game for physical attack, evoke in you all of the millions of cultural lessons regarding your racial inferiority that you have so painstakingly repressed, and imprint upon you a badge of servitude and subservience for all the world to see.

Lawrence, supra note 42 , at 461 (footnote omitted). I hope that Judge Johnson and others like him can understand that these differences do not imply that there can be no common cause between blacks and whites committed to racial justice and equality. In fact, an effective alliance requires the recognition of these differences.

65. "[F]ailing to notice another's pain is an act with significance." Martha Minow, The Supreme Court, 1986 Term-Foreword: Justice Engendered, 101 HARV. L. REV. 10, 11 (1987).

66. Lawrence, supra note 42 , at 466. 
forces. Indeed, while the First Amendment may once have been easily reconcilable with slavery and racial discrimination, one lesson of the Civil War Amendments is that the Bill of Rights, including the First Amendment, should be read in the context of the fight to overcome discrimination against minorities. ${ }^{67}$ That the First Amendment has not always been a tool for liberation, does not mean that it ought not become one.

\section{A. The Legacy of Plessy and Pace Revisited}

The Hunt plaintiffs maintained that the State of Alabama's decision to fly a symbol of white supremacy above the seat of government chilled their ability to speak freely and openly. As it had done in the Fourteenth Amendment context, ${ }^{68}$ the court rejected this argument using reasoning reminiscent of the nineteenth century. The court found no judicially cognizable chilling effect, noting that even if government speech causes "discomfort," if there "is no statute or ordinance, federal or state, absolutely prohibiting" blacks from exercising a protected First Amendment right, no First Amendment violation has occurred. ${ }^{69}$ Because the plaintiffs" problem was their "own emotions,"70 rather than the law, they would have to turn elsewhere for relief. The Hunt court cautioned that " $[t]$ he federal judiciary is not empowered to make decisions based on social sensitivity.""1

The Hunt plaintiffs, like Homer Adolph Plessy, contended that they were the victims of discrimination. But, like Plessy, they were told that their problem was personal, not legal; their problem was of their own creation, rather than State imposed. Instead of granting relief, the Plessy and Hunt courts effectively urged that the plaintiffs adjust to the presence of segregated train cars and Confederate flags. However, just as the legacy of Plessy and Pace can be purged from the Fourteenth Amendment context, so too can it be eliminated from First Amendment jurisprudence. Doing so will allow for the development of a robust conception of free speech, one that recognizes that a true commitment to wide-open debate does not leave room for government speech aimed at silencing subordinated groups.

67. See Akhil R. Amar, The Bill of Rights as a Constitution, 100 YALE L.J. 1131, 1201-02 (1991) [hereinafter Amar, Bill of Rights I]. Amar suggests that our current understanding of the original Bill of Rights is thoroughly influenced by the Fourteenth Amendment in ways that we have not yet recognized. This tentative thesis is explored more fully in Akhil R. Amar, The Bill of Rights and the Fourteenth Amendment, 101 YALE L.J. (forthcoming May 1992).

68. See supra Part I.C.

69. NAACP v. Hunt, 891 F.2d 1555,1565 (1 th Cir. 1990).

70. Id.

71. Id. 


\section{B. Recasting the Racist Speech Debate: The Government as Speaker}

Traditionally, group defamation and racial harassment cases have produced a tension between constitutional values. On one side, blacks or Jews argue that racist speech is a form of hate speech that impinges on their rights to free speech and equality. On the other side, racist speakers protest that the First Amendment protects their right to engage in racist speech. ${ }^{72}$ This tension, however, does not exist when the government is the speaker, for the First Amendment protects an individual's right to speak, not the government's.

The reluctance to provide a remedy for racist speech stems in part from the concern that the remedy will abridge the First Amendment rights of others. ${ }^{73}$ But this concern is not present in the case of a Confederate flag flying above a state capitol dome. The Confederate flag case involves no private speakers who would be silenced, at least temporarily, by the regulation or prohibition of the racist speech. The Confederate flag case has no Nazis, no Klansmen, and no university students. ${ }^{74}$ It has only the government. And the government cannot take refuge in an Amendment that provides that the government "shall make no law ....."

Indeed, as James Madison said, "If we advert to the nature of Republican Government, we shall find that the censorial power is in the people over the Government, and not in the Government over the people."75 Justice Stewart agreed when he wrote, "The First Amendment protects the press from governmental interference; it confers no analogous protection on the Government."76 The common understanding of the First Amendment as a limit on government,

72. See, e.g., Brandenburg v. Ohio, 395 U.S. 444 (1969); Beauharnais v. Illinois, 343 U.S. 250 (1952); Collin v. Smith, 578 F.2d 1197 (7th Cir.), cert. denied, 439 U.S. 916 (1978); Doe v. University of Mich., 721 F. Supp. 852 (E.D. Mich. 1989).

73. This sentiment was captured by William Van Alstyne when he said, "the remedy of silence is generally not the way of the first amendment." William W. Van Alstyne, The First Amendment and the Suppression of Warmongering Propaganda in the United States: Comments and Footnotes, 31 LAW \& CONTEMP. PROBS. 530, 535 (1966). This principle was also stated by Justice Brandeis in his concurrence in Whitney v. California: "If there be time to expose through discussion the falsehood and fallacies, to avert the evil by the processes of education, the remedy to be applied is more speech, not enforced silence." 274 U.S. 357, 377 (1927).

74. The Confederate flag case is not, for example, Brandenburg, 395 U.S. 444, in which the Supreme Court upheld a Klan leader's right to advocate racial violence. Nor is it Doe, $721 \mathrm{~F}$. Supp. 852, in which a district court struck down the University of Michigan's code regulating hate speech. And it does not resemble Collin, 578 F.2d 1197, in which the Seventh Circuit ruled unconstitutional the City of Skokie's decision to deny a marching permit to a group of Nazis. In fact, at least one writer discussing the Skokie case notes that it would have been a different and easier case if the government, rather than individuals, were the speaker. Edward L. Rubin argues that "[t]he problem [ with prohibiting the demonstration] is that such a demonstration is not simply protected speech; it is, together with the newspaper editorial, our quintessential image of protected speech." Edward L. Rubin, Nazis. Skokie, and the First Amendment as Virtue, 74 CAL. L. REV. 233, 235 (1986) (book review). However, Rubin points out that if the government were promoting the symbols of the Nazi period the case would have been decided differently: "Obviously the government may not engage in racial vilification, but that presents no conflict, since the first amendment does not confer free speech rights upon the government." Id. at 247.

75. 4 ANNALS OF CONG. 934 (1794) (quoted in Van Alstyne, supra note 73, at 532 n.5).

76. CBS v. Democratic Nat'l Comm., 412 U.S. 94, 139 (1972) (Stewart, J., concurring). 
rather than a license for it to speak, is natural given the language of the amendment: "Congress shall make no law . . . abridging the freedom of speech, or of the press; or the right of the people peaceably to assemble, and to petition the Government for a redress of grievances."77 To transform a restriction on government into a positive right vested in the state would do violence to the Amendment's language. Indeed, a natural reading of the First Amendment allowed Thomas Emerson to conclude that, "there is no real paradox involved in invoking the First Amendment to restrict government expression. The purpose of the First Amendment is to protect private expression," not that of the government. ${ }^{78}$

Recognizing that the Confederate flag argument is not a debate about competing First Amendment rights has profound implications for its chances of success. ${ }^{79}$ Under this new formulation, blacks advance First and Fourteenth Amendment arguments on one side, while the government can only rebut those arguments, rather than advance positive First Amendment arguments of its own. If the government does try to assert a positive argument for its speech rights, it must be an argument that focuses on the importance of the speech in furthering a legitimate government function. It will take a creative legal mind to explain the utility of flying Dixie. ${ }^{80}$

\section{A Theory of Government Speech}

Because the government is the speaker, a different balance of interests arises than is normally presented in the battle between racist speakers and their victims. It thus becomes possible to construct a distinct free speech theory when the government is the speaker. The development of such a theory has already

77. U.S. CONST. amend I. The limitation on Congress is also a limitation on the states. The Court held in Gitlow v. New York, 268 U.S. 652 (1925), that the First Amendment applied via the Fourteenth to state governments.

78. THOMAS I. EMERSON, THE SYSTEM OF FREEDOM OF EXPRESSION 700 (1968); see also Amar, Bill of Rights $I$, supra note 67 , at 1147 .

79. This distinction should not imply that the more traditional hate speech claims are being correctly decided. The editors of the Harvard Law Review, for example, in criticizing Doe v. University of Michigan, 721 F. Supp. 852 (E.D. Mich. 1989), have provided an alternative approach that would leave courts better equipped to balance competing First Amendment claims, even when both claimants are private individuals. They have argued that courts should not apply the categorization analysis used in Doe, but rather a contextual analysis that would involve balancing competing First Amendment claims. They write,

[T] he court [in Doe] employed categorization analysis, which permits content-based restrictions only of speech that falls into one of a few, narrow categories, regardless of countervailing interests. Though maximizing protection of important first amendment interests, categorization undervalues the potentially conflicting norm of equality; indeed, it may actually perpetuate discrimination. A better approach would have courts employ a contextual analysis that fully weighs both the harm hate speech inflicts on minority and women students and the need to ensure the airing of all ideas.

Recent Cases, 103 HARV. L. REV. 1397, 1397 (1990) (footnote omitted). The adoption of such an analysis first requires that courts take seriousiy the claims made by victims of racial speech. To date, unfortunately, such sensitivity has been notably absent.

80. See supra text accompanying notes 31-33. 
begun, for although the First Amendment has traditionally been thought of as a limit on the government's ability to regulate the speech of private citizens, the past fifteen years have seen a growing number of scholars arguing that the First Amendment also limits the government's ability to speak. In other words, not only does the First Amendment provide no protection for government speech, it may prohibit certain types of government speech. "[S]trange as it must sound in appraising an amendment which explicitly forbids abridging the freedom of speech, it is nonetheless arguable that the function of that amendment implicitly requires some silencing of the government itself." $\$ 1$ Starting with the presumption that the First Amendment may mandate some limits on government speech, I will analyze the Confederate flag case in the context of government speech doctrine and will suggest a theory of government speech that would require removing the flag.

Any discussion of government speech doctrine must begin with an understanding that the Supreme Court has yet to squarely address the problem presented by discriminatory government speech. Three lines of cases are often grouped under the heading of government speech: compelled speech cases, drowning-out cases, and public forum cases. In the compelled speech cases, individuals claimed that the government was forcing them to adopt and profess certain beliefs. The two most frequently discussed government speech cases, West Virginia State Board of Education v. Barnette, ${ }^{82}$ and Wooley v. Maynard ${ }^{83}$ illustrate the principle that a state may not compel allegiance or orthodoxy. Yet neither case prohibits the state from presenting its viewpoint. In the drowning-out cases, individuals claimed that the government allowed the speech of the powerful to drown them out, thereby limiting their First Amendment rights. ${ }^{84}$ However, these cases do not truly involve government speech: the

81. Van Alstyne, supra note 73 , at 532.

82. 319 U.S. 624 (1943).

83. 430 U.S. 705 (1977).

84. Here, the Court historically has shown little patience with the argument that some speech is so dominant that it threatens to violate the First Amendment by stifling the viewpoints of others. In Miami Herald Publishing Co. v. Tornillo, 418 U.S. 241 (1974), the Court struck down a state law guaranteeing an individual the right of reply when criticized by a newspaper. The Court rejected Tornillo's argument that the truth would not emerge unless he was allowed to participate in the marketplace of ideas. Similarly, in Buckley v. Valeo, 424 U.S. 1 (1976), the Court struck down portions of the Federal Election Campaign Act of 1971 that limited the amount of money that could be spent on elections. The Court explicitly rejected the drowning-out theory, saying, "the concept that government may restrict the speech of some elements of our society in order to enhance the relative voice of others is wholly foreign to the First Amendment ..." Id. at 48-49. Similar cases have applied this theory to corporations. For example, in First Nat'1 Bank of Boston v. Bellotti, 435 U.S. 765 (1978), the Court reviewed a Massachusetts statute that prohibited corporations from spending money to influence voter referenda unless the issue directly affected the corporation's property, business, or assets. One of the state's arguments was that "corporations are wealthy and powerful and their views may drown out other points of view." Id. at 789. The Court rejected this argument, citing Buckley.

The Court, however, recently demonstrated a willingness to modify its Buckley and Bellorti reasoning and recognize that the speech of the powerful may unduly dominate the arena of political discourse. In Austin v. Michigan Chamber of Commerce, 110 S. Ct. 1391 (1990), the Court upheld a Michigan statute limiting independent campaign expenditures by corporations. The Court noted that "corporations may accumulate large amounts of wealth" and that a "unique state-conferred corporate structure facilitates this 
powerful speakers in these cases were private parties, not the government. Finally, the public forum cases have presented the Court with the problem of determining the circumstances under which a space has become a public forum and the extent to which the government may regulate the use of such a forum..$^{85}$ Like the drowning-out cases, however, the public forum cases present a rather attenuated version of government speech. Here too, the government is not itself the speaker, but instead merely regulates the speech of nongovernmental entities. In sum, although the compelled speech, drowning-out, and public forum cases all involve speech and the government, they do not involve speech by the government.

In addressing the Confederate flag claim, the Hunt court attempted to fit the case into one of the three existing lines. When it did not fit, the court concluded that a government speech analysis was inappropriate. ${ }^{86}$ However, when faced with a novel case, which does not fit neatly into existing categories, a court should not apply existing case law mechanically. It should instead examine the rationale underlying the existing doctrine. While the Supreme Court has only recognized the three existing lines, it has never characterized these lines as the outermost limits. To the contrary, the Court has recognized that "it is a central tenet of the First Amendment that the government must

wealth accumulation." Id. at 1398. According to the Court, "the immense aggregations of wealth that are accumulated with the help of the corporate form and that have little or no correlation to the public's support for the corporation's political ideas," could serve to corrode and distort the political process. Id. at 1397.

85. These cases are not a model of clarity. In Police Department of Chicago v. Mosley, 408 U.S. 92 (1972), the Court reviewed a Chicago ordinance that regulated picketing near school buildings. Under the ordinance, labor picketing was permitted; other forms of picketing were not. The Court struck down the ordinance on the ground that it drew content, rather than time, place, and manner distinctions. $I d$. at 99 . The Court also attempted to establish a framework for evaluating public forum cases. It said:

There is an "equality of status in the field of ideas," and government must afford all points of view an equal opportunity to be heard. Once a forum is opened up to assembly or speaking by some groups, government may not prohibit others from assembling or speaking on the basis of what they intend to say.

Id. at 96 (quoting ALEXANDER MEIKLEJOHN, POLTICAL FREEDOM: THE CONSTITUTIONAL POWERS OF THE PEOPLE 2 (1948)). In Mosley's companion case, Grayned v. City of Rockford, 408 U.S. 104 (1972), the Court moved away from its policy of granting access to those areas that were traditionally public forums while denying it to those areas that were not. The Court announced that a private group's right of access did not hinge on the traditional role of the forum, but rather on whether or not the group's "manner of expression [was compatible] with the normal activity of a particular place at a particular time." Id. at 116 . However, in Greer v. Spock, 424 U.S. 828 (1976), the Court did an about-face and ruled that a political group did not have a right of access to a military base because the base was not a traditional public forum. The Court also followed the Mosley principle in Southeastern Promotions, Ltd. v. Conrad, 420 U.S. 546 (1975), when it held that the city of Chattanooga could not refuse to allow a group to use its municipal auditorium on the grounds that the performance would not be, in the words of the city, "clean and healthful and culturally uplifting." Id. at 554 n.7. However, the Court took a different tack in Lehman v. City of Shaker Heights, 418 U.S. 298 (1974), when it upheld a government regulation permitting private groups to use bus space for commercial, but not political, advertising. It is unclear why the Court did not apply Mosley and decide that since the forum had been opened, all had a right to use it. In the last decade, the Court has upheld a number of speech restrictions by narrowing the definition of what constitutes a public forum. See, e.g., United States v. Kokinda, 110 S. Ct. 3115 (1990) (sidewalk in front of post office not a public forum); Perry Educ. Ass'n. v. Perry Local Educators' Ass'n,. 460 U.S. 37 (1983) (school mailbox system not a public forum).

86. NAACP v. Hunt, 891 F.2d 1555, 1566 (11th Cir. 1990). 
remain neutral in the marketplace of ideas." 87 Although the Court has used this principle only to evaluate government regulation of speech, not speech by the government itself, the maxim nonetheless strongly suggests that when government speaks, the First Amendment may place limitations on what it says.

The attempt to develop a theory of government speech must recognize that much of what the government has to say is either essential to governing or a useful contribution to the marketplace of ideas. ${ }^{88}$ In light of the important values that government speech can serve, any theory restricting government speech must be carefully tailored to ensure that the government is not prevented from saying things that need saying. ${ }^{89}$

It is equally clear, however, that the core values of the First Amendment are particularly threatened by government speech that encourages discrimination against and subordination of disadvantaged social groups. Such speech serves no legitimate government function and, indeed, may inhibit a portion of the citizenry from fully participating in the process of governing..$^{90}$ Accordingly, this Note suggests a theory of government speech that would prohibit such discriminatory speech by the government. The starting point for this theory is a developing First Amendment literature imbued with the understanding that protecting the speech rights of some can damage the speech rights of others. Owen Fiss, for example, argues that in a world of social, economic, and

87. Hustler Magazine v. Falwell, 485 U.S. 46, 56 (1988) (quoting FCC v. Pacifica Foundation, 438 U.S. $726,745-46(1978)$ ).

88. As Thomas Emerson stated:

Participation by the government in the system of freedom of expression is an essential feature of any democratic society. It enables the government to inform, explain, and persuade-measures especially crucial in a society that attempts to govern itself with a minimum use of force. Government participation also greatly enriches the system; it provides the facts, ideas, and expertise not available from other sources.

EMERSON, supra note 78, at 698.

89. Yudof identifies line drawing as one of the principal problems with attempting to limit government speech. MARK G. YUDOF, WHEN GOVERNMENT SPEAKS 41-42 (1983). Each scholar who has addressed the government speech question has developed a different test for measuring what speech should be allowed. Thomas Emerson, one of the first to discuss government speech, indicated that a "government's right of expression does not extend to any sphere that is outside the governmental function." EMERSON, supra note 78 , at 699 . For example, "government would not be empowered to engage in expression in direct support of a particular candidate for office" because "[i]t is not the function of the government to get itself reelected." Id. The Harvard Law Review suggests an "intellectual domination" test: Although "[a] mere showing that government speech burdens private speech should not by itself mandate invalidation of the government expression," the speech can be limited if it "threatens to produce government domination of the intellectual marketplace." Recent Cases, supra note 79, at 219. Steven Shiffrin suggests an "eclectic" balancing approach that would weigh the value of government speech against possible harms. Steven Shiffrin, Government Speech, 27 UCLA L. REv. 565, 607-17 (1980). Finally, Robert Kamenshine would have courts recognize a political Establishment Clause similar to the establishment clause for religion. Robert D. Kamenshine, The First Amendment's Implied Political Establishment Clause, 67 CAL. L. REv. 1104, 1109 (1979). Kamenshine suggests that government dissemination of political speech threatens the marketplace of ideas because of the government's hegemonic influence. Since existing First Amendment interpretations do not adequately protect against government dissemination of political viewpoints, he suggests that government political speech should be subject to strict scrutiny. Under his model, an individual would be protected against government speech when it infringed on her ability to speak, but that infringement would not have to rise to the level of a First Amendment violation.

90. See infra notes $99-106$ and accompanying text. 
political inequality, providing a First Amendment shield behind which all speakers can take shelter may work against the underlying free speech values the First Amendment is dedicated to protecting. ${ }^{91}$ Similarly, Catharine MacKinnon and Andrea Dworkin discuss the extent to which protecting the speech of pornographers has the effect of silencing women. ${ }^{22}$

More specifically, the 1980's have seen the development of a growing literature on the evils of racist hate speech. Richard Delgado and Mari Matsuda have both written ground-breaking articles on the topic. ${ }^{93}$ They argue that racist speech has a direct debilitating effect on its victims. ${ }^{94}$ According to Matsuda, "[t]olerance of hate speech is not tolerance borne by the community at large. Rather, it is a psychic tax imposed on those least able to pay." 95 Moreover, they argue that racist speech undergirds a social system dedicated to white supremacy. ${ }^{96}$

While the racist speech literature has not focused on government speech, its lessons apply with redoubled force in this context. Taking seriously the harm

91. Owen M. Fiss, Free Speech and Social Structure, 71 IOWA L. REv. 1405 (1986). According to Fiss, the free speech tradition envisions a street corner speaker on a soapbox.

The crucial assumption in this theory is that the protection of autonomy will produce a public debate that will be ... "uninhibited, robust, and wide open"... From the perspective of the street corner, that assumption might seem plausible enough. But when our perspective shifts, as I insist it must, from the street corner to, say, CBS, this assumption becomes highly problematic. Autonomy and the rich public debate-the two free speech values-might diverge and become antagonistic. Under CBS, autonomy may be insufficient to insure a rich public debate. Oddly enough, it might even become destructive of that goal.

Id. at 1410 (footnote omitted).

92. CathaRINe A. MacKinnon \& ANDREa Dworkin, Pornography AND Civil Rights (1988). Of course, there are many harms produced by pornography, of which the silencing of women is only one. $I d$. at 47; see also Catharine A. MacKinnon, Pornography, Civil Rights, and Speech, 20 HARV. C.R.-C.L. L. REV. 1 (1985).

93. Richard Delgado, Words that Wound: A Tort Action for Racial Insults, Epithets, and Name-Calling, 17 HARV. C.R.-C.L. L. REV. 133 (1982); Matsuda, supra note 60; see also Lawrence, supra note 42. For a catalogue of the dozens of recent articles on hate speech, see Robert C. Post, Racist Speech, Democracy, and the First Amendment, 32 WM. \& MARY L. REV. 267, 267 n.5 (1991).

94. Delgado argues that racial hate speech stigmatizes individuals: "The psychological responses to such stigmatization consist of feelings of humiliation, isolation, and self-hatred. Consequently, it is neither unusual nor abnormal for stigmatized individuals to feel ambivalent about their self-worth and identity." Delgado, supra note 93, at 137. Similarly, Matsuda finds that victims of racist speech "have experienced physiological symptoms and emotional distress ranging from fear in the gut, rapid pulse rate and difficulty breathing, nightmares, post-traumatic stress disorder, hypertension, psychosis, and suicide."Matsuda, supra note 60, at 2336. Other writers, including those who disagree with Matsuda's and Delgado's conclusions that racist speech should be regulated, have stressed the harms such speech produces. According to Lee Bollinger, "racist speech and advocacy of genocide are protected, despite the fact that anyone seriously interested in seeking truth would spend no time listening to such ideas. We have good reason to think many ideas invalid and bad, and some come with a very high price. Some speech, in fact, has a great capacity to harm." Bollinger, supra note 61 , at 980 .

95. Matsuda, supra note 60, at 2323.

96. Racism, Matsuda says, is "the ideology of racial supremacy and the mechanism[] for keeping selected victim groups in subordinated positions." Matsuda, supra note 60 , at 2332 . Racist speech, in this formulation, is one of the ways through which racism is implemented. "From the victim's perspective, all of these implements inflict wounds, wounds that are neither random nor isolated. Gutter racism, parlor racism, corporate racism, and government racism work in coordination, reinforcing existing conditions of domination." Id. at 2335. 
that racist government speech produces allows one to see that discriminatory government speech most directly attacks the underlying principles of the First Amendment. The commitment to freedom of speech stems from the commitment to autonomous expression ${ }^{97}$ and democratic self-governance. ${ }^{98}$ Put another way, participating in the marketplace of ideas both produces personal satisfaction and furthers the quest for truth. ${ }^{99}$ However, as with any market, the marketplace of ideas is imperfect, with one of the most significant flaws being that one's social position frequently determines one's ability to participate. Traditional First Amendment jurisprudence has been criticized for ignoring these flaws. Catharine MacKinnon, for example, argues that the First Amendment's emphasis on keeping government out of the marketplace of ideas "tends to presuppose that whole segments of the population are not systematically silenced socially, prior to government action." ${ }^{100}$ This insight carries even greater force in the government speech context, for here the government has done more than fail to remedy the social silencing about which MacKinnon writes. In this case, it is the discriminatory government speech itself that corrupts and distorts the marketplace of ideas. Discriminatory speech by the government thus directly undermines both the commitment to autonomous expression and democratic self-governance by intimidating certain social groups

97. See, e.g. Whitney v. California, 274 U.S. 357, 375 (1927) (Brandeis, J., concurring) ("Those who won our independence believed that the final end of the State was to make men free to develop their faculties .... They believed liberty to be the secret of happiness and courage to be the secret of liberty."); JOHN STUART MILL, ON LIBERTY 64 (Elizabeth Rapaport ed., Hackett Publishing 1978) (1859) ("If a person possesses any tolerable amount of common sense and experience, his own mode of laying out his existence is the best, not because it is the best in itself, but because it is his own mode.").

98. See, e.g., Roth v. United States, 354 U.S. 476, 484 (1957) ("The protection given speech and press was fashioned to assure unfettered interchange of ideas for the bringing about of political and social changes desired by the people"); Whitney, 274 U.S. at 375 (Brandeis, J., concurring) (The Founders "believed that freedom to think as you will and to speak as you think are means indispensable to the discovery and spread of political truth ...."); ALEXANDER MEIKLEJOHN, POLITICAL FREEDOM 27 (1948) ("The principle of the freedom of speech springs from the necessities of the program of self-government.").

99. The marketplace of ideas metaphor is linked strongly to a free speech model that emphasizes speech as integral to a healthy democracy. Its roots in First Amendment jurisprudence can be found in Justice Holmes' dissent in Abrams v. United States, 250 U.S. 616 (1919). "But when men have realized that time has upset many fighting faiths," wrote Holmes, "they may come to believe . . . that the ultimate good desired is better reached by free trade in ideas-that the best test of truth is the power of the thought to get itself accepted in the competition of the market." Id. at 630 (Holmes, J., dissenting).

100. Catharine A. Mackinnon, Not a Moral Issue, 2 YALE L. \& PoL'Y REV. 321, 340 (1984); see also Lawrence, supra note 42 , at 468 ("[I]t is not just the prevalence and strength of the idea of racism that makes the unregulated marketplace of ideas an untenable paradigm for those individuals who seek full and equal personhood for all. The real problem is that the idea of the racial inferiority of non-whites infects, skews, and disables the operation of the market (like a computer virus, sick cattle, or diseased wheat)."). 
into refraining from expression, thereby vitiating their autonomous expression rights and impoverishing public discourse. ${ }^{101}$

An understanding of the corrupting force discriminatory government speech exerts on the marketplace highlights the final reason for restricting such speech: it undermines the democratic process. In United States v. Carolene Products Co., the Court stated that judicial deference to legislative judgment should end when the legislative decision under review has restricted the "political processes which can ordinarily be expected to bring about repeal of undesirable legislation." 102 Drawing on this point, John Hart Ely argues that legislative decisions limiting participation in the political process should be subject to the highest scrutiny. ${ }^{103}$ Racist government speech is precisely the type of legislative action that restricts the political process. When the state flies the Confederate flag, it flies a flag that was introduced to lead Southern troops into battle in their war for control of their land and slaves. ${ }^{104}$ It flies a flag reintroduced during a period of state opposition to the black equality movement. ${ }^{105}$ It flies a flag that has been used as the symbol of the Ku Klux Klan, the nation's premier white supremacist organization, and has subsequently been adopted as a symbol by other racist groups. ${ }^{106}$ When the government flies this flag, it is not creating an environment conducive to uninhibited debate by its black citizens. Nor is it creating an environment that encourages blacks to exercise their right to petition government for redress of grievances. The flag's message of exclusion and contempt can only work to discourage political participation of the excluded. It is hardly representation reinforcing. ${ }^{107}$

The Confederate flag case drives home the need for a theory of government speech that takes seriously the intuition of Carolene Products. In Hunt, the court suggested that the plaintiffs turn to their state legislature, not to the federal judiciary, for relief. The court's reasoning deserves close attention:

It is unfortunate that the State of Alabama chooses to utilize its property in a manner which offends a large proportion of the population, but that is a political matter which is not within our province to decide. The remedy for such a grievance lies within the democratic processes

101. Again, understanding the manner in which discriminatory government speech undermines the First Amendment requires an understanding of the social forces at play. As the Court recognized in NAACP v. Button, 371 U.S. 415, 435-36 (1963), the force. and the potential discriminatory implications, of a particular government policy cannot be comprehended without examining its relationship to other government policies. In the case of the Confederate flag, the racist government speech achieves its silencing power from the understanding on the part of victims that a real, and powerful, state and society remain prepared to back up the flag's message.

102. United States v. Carolene Products Co., 304 U.S. 144, 152 n.4 (1938).

103. JOHN H. ELY, DEMOCRACY AND DISTRUST (1980).

104. The Stars and Bars is Not a Racist Symbol, supra note 2.

105. See supra notes 3-6 and accompanying text.

106. See sources cited supra note 57 .

107. This argument has been made in relation to municipal advocacy in state referenda campaigns. See Note, The Constitutionality of Municipal Advocacy in Statewide Referendum Campaigns, 93 HARV. L. REV. 535, 555-56 (1980). 
of the State of Alabama and the voting rights of all its citizens .... 108

Hunt's suggestion is somewhat ironic because it was the Alabama state government itself which raised the flag and continues to fly it. The Hunt court did not understand that racist government speech violates the First Amendment precisely because such speech makes it that much more difficult for those who oppose government policy to give voice to their opposition.

\section{CONCLUSION}

It is the spring of 1984 in Atlanta, and the groundskeeper at Franklin Delano Roosevelt High School is starting his morning routine. In my twelfth grade homeroom we have finished the morning business-attendance has been taken, the announcements have been made. We are simply waiting for the bell to signal the start of the first class period. As I wait, my eyes return to the groundskeeper, who is carefully unfurling and raising a series of flags. First is the American flag, last is the Atlanta Public Schools flag, and sandwiched between the two is the Georgia State flag. I am drawn to this flag, particularly to its wholesale incorporation of Dixie. I observe the same scene almost every morning, and almost every morning I hate the fact that I watch. I want so desperately to ignore the flag, ignore Dixie, and ignore the history for which it stands.

For relief, I take my eyes off the flag and glance down again at the groundskeeper, who is still pulling the cords to raise the trio of flags. Like most of the students and teachers, the groundskeeper is black. I think of the incongruity of having black children, in a largely black city, watch a black man raise the symbol of the Confederacy for us all to honor. I tell myself to laugh, hoping that this will keep me from crying. But I cannot laugh, and I dare not cry, so I close my eyes and try to forget. If I could just forget. My eyes close tightly, my fists clench, and I slowly force from my mind images of the flag, of the $\mathrm{Ku}$ Klux Klan, of Bull Conner and George Wallace-of black people in chains, hanging from trees, kept illiterate, denied the opportunity to vote.

The bell has rung. My teacher is calling my name: "James, are you ok?" I look up, startled. "Yes ma'am, I'm fine," I say, as I collect my books and head for class. "I'm fine," I repeat to myself, as I walk out the door. I have forgotten; I have purged my mind; I am able to get up and walk out of the door. But overcoming the flag has taken a piece of me-a piece that I will not easily recover.

108. NAACP v. Hunt, 891 F.2d 1555, 1566 (11 th Cir. 1990). 